\title{
Chilean Trade 1880-1930: A Comment on the Sources for the Age of Exports
}

\section{Introduction}

This article provides an overview of the main sources, data availability and accuracy for studying the age of exports in Chile. After independence, and until 1880, silver, copper and wheat were the main tradable products. From then, that is after the Pacific War, until the Great Depression, the nitrate cycle drove the expansion of the Chilean economy into international markets. Badia-Miró and Díaz-Bahamonde (2017) affirm the contribution of exports to the country's economic growth; exceeding 20-25\% of total GDP, between 1880 and 1920 (including the direct contribution, the return value of exports, the ability to import, external economies and linkages). In this paper we briefly discuss the main figures supplied by foreign trade statistics and their accuracy. We focus our analysis on the period 1880-1930 to help to understand the integration of Latin American trade into the world system.

Unlike other countries, Chile has an array of different sources of information that help to understand the evolution of its economy and its export sector, in the long run. Although most researches have accepted foreign trade figures derived from official yearbooks and highlight the Chilean case as an example of the reliability of their sources, other authors have questioned them. For instance, Salazar (1984, 2009) and Llona (2012) point out the existence of problems of valuation in the sources from the $19^{\text {th }}$ century.

Nevertheless, our main conclusion is that while the available sources have limitations, figures derived from trade statistics still allow us to examine the performance of Chilean foreign trade within an acceptable margin of error. Moreover, one outstanding feature is the availability and replicability of the figures; a factor which implies that improved figures could be obtained with further research. 
The paper is structured as follows. In the next section we discuss the Chilean foreign trade statistics that are mainly used to obtain total export and import figures (values, prices and quantum). The third section is focused on product analysis and the fourth on the accuracy of bilateral foreign trade sources. The fifth section concludes.

\section{Total Exports and Imports}

Chile continues to be mainly a mining export economy. After independence the main products exported by Chile were wheat, silver and copper. Wheat was Chile's main agricultural commodity until 1879 , although it never surpassed the share of mining exports. From 1880 until the Great Depression, the leading Chilean export was saltpetre, or potassium nitrate (Butelmann et al., 1981). Between 1906 and 1910, nitrates comprised $75 \%$ of total exports, and direct taxes on exports accounted for $58 \%$ of fiscal revenues (Meller, 1998).

It should be noted that after independence, Chile maintained its former colonial markets with neighbouring countries, together with the new markets of the United Kingdom and the east coast of the US; which demanded a huge quantity of products due to their economic expansion during the Industrial Revolution. In addition, taking advantage of the fall in trade costs and the expansion of new settler economies, new markets were added: the west coast of the US and Australia (Collier and Sater, 2004).

The war with Peru and Bolivia between 1879 and 1883 was a dramatic turning point for the Chilean economy. The occupation of the northern regions allowed Chile to expand nitrate production (and nitrate exports), and the political instability of its neighbours broke the former colonial trade networks. Exports underwent a severe concentration process, both of product and of market destination (nitrates and the United Kingdom, respectively). By the end of the mining cycle, just four countries imported more than $90 \%$ of total Chilean exports (Great Britain, the United States, France and Germany), 
while other countries played a secondary role, specifically Chile's existing trade with its South American neighbours (Carreras-Marín et al., 2013).

\subsection{The Main Sources}

As Mamalakis (1978) states, Chile has a broad collection of trade, current account, and balance-of-payments statistics. The most important primary source of trade and balance-of-payments statistics for the pre-1925 years comprises the publications of the statistical and census bureau (Dirección General de Estadistica). The report of the "Societe des Nations" (1928: pp. 201-3), indicated that prior to 1916, import values for Chile were official values that commenced in 1897 and were revised every five years to obtain a better adjustment to real values. After 1916, the Chilean statistics comprised "declared values". Export values were declared free on board, "a precio corriente de plaza". From 1925 onwards, the reports of the Central Bank became the main source of information.

Díaz et al. (2016) provide figures for total exports and imports by splicing various sources. The original trade data came from official sources and were reported in various units of account provided by the following sources (all of them were converted to current dollars):

- 1810-1844: based on estimates provided by Rector (1985) and interpolated with data from Ibañez (1912). Data for this period are scarce and unreliable, especially when compared to the later period, so this indicator should be treated as provisional. However, general trends of production, the foreign trade statistics of partner countries and the figures provided by Salazar (2009), taken together corroborate consideration of these numbers as reasonable guesstimates.

- 1844-1861: the data came from Ibáñez (1912) in current pesos and were converted to dollars with the exchange rate of Díaz et al. (2016). 
- 1862-1925: the data came from OCE (1925). The original data were in 6d pesos; "a fictional unit of constant gold content", as Llona (2012) put it, and were converted to dollars with the exchange rate of Díaz et al. (2016).

- 1926-1930: SNECCh (1930). The original data were in 6d pesos.

Most of the international databases used reported data for the total imports and exports of Chile, broadly speaking, although the original sources are diverse. Federico and Tena-Junguito (2016) considered the figures of Braun et al. (2000) in current dollars, for the period 1810-1938. For total exports in US dollars, MOXLAD (2011) considered Palma's (1979) growth rate of exports in pounds sterling, for the period 1900-1905. For the rest of the period, they considered Hofman's (2000) figures. Imports from MOXLAD (2011) are also taken from Hofman (2000). Barbieri and Keshk (2012) and Barbieri et al. (2009) showed total import and total exports in US dollars from secondary sources. They show some discrepancies with the other databases reported, especially prior to 1895 . RICardo (2016) also shows data for total exports and imports of Chile in local currency and in pounds sterling. When we apply the exchange rate suggested by Federico and Tena-Junguito (2016) to convert trade figures into current dollars, some discrepancies with the previous figures appear (see Figures 1 and 2).

Figure 1- Total Exports of Chile, 1845 - 1938 (\$US current)

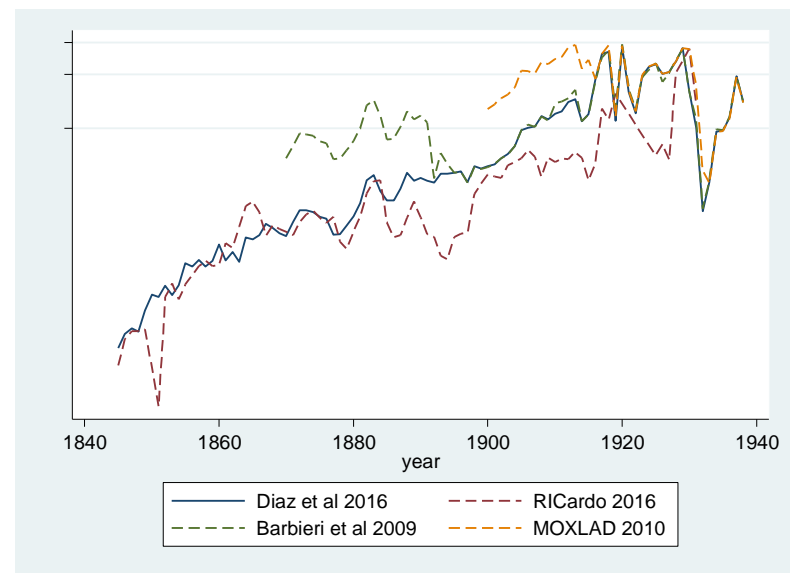


Source: Díaz et al. (2016), Barbieri et al. (2009), RICardo (2016) and MOXLAD (2011).

Figure 2 - Total Imports of Chile, 1845 - 1938 (\$US current)

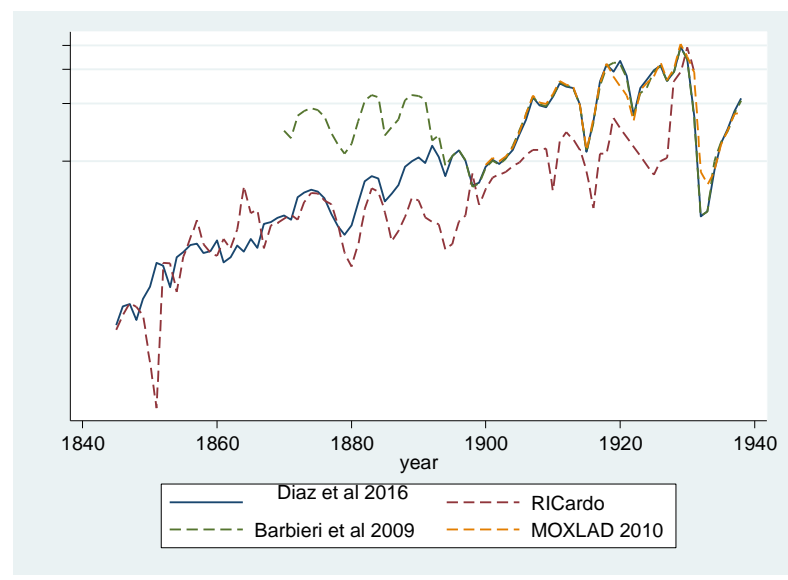

Source: Díaz et al. (2016), Barbieri et al. (2009), RICardo (2016) and MOXLAD (2011).

For the period before 1880, RICardo (2016) and Díaz et al. (2016) show a close similarity because they used the same original sources. For subsequent years, through the 1880s and the beginning of the 20th century, RICardo (2016) shows a stagnation in export and import figures. On the other hand, Díaz et al. (2016) and Barbieri and Keshk (2012) show a similar pattern after 1895 and a positive trend during the early 1900 s and 1910 s. In most of the series, although we observe a peak in 1910, the levels reached were below the levels of the 1920s. However, MOXLAD (2011) figures show big differences before World War I, with nitrate expansion pushing exports to their maximum in 1910, at similar levels to those reached during the 1920s.

As all the series considered reported the same original sources, discrepancies must come either from differences in the exchange rate used in the conversion, or from differences in the treatment of the unit of account reported in the source. As we have said, official Chilean trade figures were reported using "a fictional unit of constant gold content", and its conversion into current values is not simple (Llona, 2012). 
Comparing all these sources, we confirm that the best available figures to understand Chilean total trade performance are those provided by Díaz et al. (2016). They consider the original local sources with the most widely used exchange rates. They also report the shortcomings assumed, which ensures replicability and the capacity for later improvements. At the same time, other economic indicators and secondary sources observed, for the nitrate cycle, fit quite well with the peak in saltpetre exports just before WWI.

\subsection{Export and Import Price Indexes}

Discussion about the construction of price indexes of imports and exports is still ongoing. The most widely used figures are those provided by Díaz et al. (2016). These authors built their figures by connecting the growth rates of various previously estimated indexes:

- 1810-1843: for the export price index, the authors assumed the price index of Lima (Gootenberg, 1989). This is a plausible guesstimate, as trade with Peru was very important for Chile during this period, as Cáceres (2013) pointed out. For the import price index, they assumed the wholesale price index of the United Kingdom.

- 1844-1860: indexes provided by Palma (1979: Appendix 18).

- 1861-1899: figures from Clavel (1990); based on dynamic prices and changing baskets, enabling him to build a Paasche index of unit prices of imports and exports. The data came from official foreign trade statistics.

- 1900-1927: ECLAC (1951: Table 2A). In this case, unit prices of imports came from the Chilean Statistics (1936) for the period 1900-1924. For 19251928, figures were built from the basis of a Paasche index with official data from foreign trade statistics. 
- 1928-1959: unit import and export series in Banco Central de Chile (1962: pp. 20-22).

Other series of import and export prices are reported by MOXLAD (2011), which considered ECLAC (1951, 1976). In both cases, data were obtained from Paasche indices considering international prices and baskets from the official foreign trade statistics.

A third set of price indexes came from Palma (1979: Appendices 18 and 32), and is partially used by Díaz et al. (2016), for the period 1844-66. For the period 1870-1879 he considered a Paasche price index of various products. For the period 1880-1900 he followed a Paasche index, considering a basket of products built from official sources of foreign trade. He combined these products with international prices. ${ }^{1}$ In the case of the import unit price for the period 1870-1899 he used the UK export price index from Feinstein (1972). For the period 1900-1935, as in the previous works, he followed ECLAC (1951). ${ }^{2}$

A fourth, new data source is provided by Badia-Miró and Carreras-Marín (2016). They built new figures for export prices from Paasche indices for 1885-1950, considering different benchmarks. The result has been corrected to take into account trade costs. ${ }^{3}$ They obtained an import unit price for Chile from the export unit prices of the main trading partners, weighted by each country's share of the total import figure, and they adjusted it to take into account bilateral trade costs.

In the case of Chile, export prices from all the sources follow similar trends during most of the period. Although we observe clear discrepancies during World War I, its impact on performance, in terms of trade, is limited (import prices also experienced a

\footnotetext{
${ }^{1}$ In all the cases, he considered Sauerbeck's prices cited in Mitchell and Deane (1962).

${ }^{2}$ As a part of a more wide research agenda Francis (2015) has criticized several of the sources above mentioned without providing a reasonable alternative series.

3 These authors correct international prices to obtain "domestic prices" for most of exported products considering the trade costs computed in Badia-Miró et al. (2018) to adjust it.
} 
high rise and, therefore, the general trend remained quite similar to the other figures). To sum up, Badia-Miró and Carreras-Marín (2016) observe a smaller drop in export price levels at the end of $19^{\text {th }}$ century and the beginning of the $20^{\text {th }}$ century, while the fall in prices during the Great Depression was much more pronounced. We confirm that the series provided by Badia-Miró and Carreras-Marín (2016) looks promising, as they provide a better export basket and spatially diversified import price index.

\subsection{Quantum Indexes of Exports and Imports}

Implicit quantum indexes can be obtained as the ratio between a value index and a price index. In our case, we will compare the quantum index of exports and imports which results from both price indexes: the one provided by Díaz et al. (2016) and that provided by Badia-Miró and Carreras-Marín (2016). Both exports and imports expanded in quantum during the nitrate cycle, until World War I. It seems clear that the expansion started before the Pacific War and the occupation of the Northern provinces. Quantum growth was also important during the wheat and copper export expansion of the $1860 \mathrm{~s}$ and 1870s. Nevertheless, the export quantum stagnated during the 1920s, with a higher level of volatility. We also observe a coincidence in the dramatic fall of the Great Depression, where the contraction in quantities was as important as the price collapse.

Figure 3 - Export quantum index, 1850-1938 (1913=100)

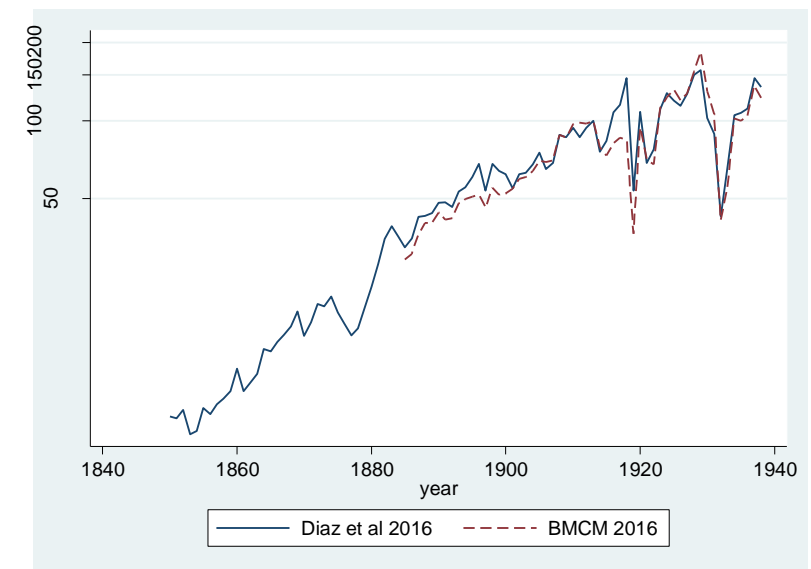


Source: Badia-Miró and Carreras-Marín (2016) and Díaz et al. (2016)

When observing export quantum (see Figure 3), discrepancies in both series are small because the export price indexes in both sources are quite similar, due to the predominance of saltpeter as the leading export commodity during most of the period, and the use of international prices (non-corrected).

The expansion of the import quantum was also important during the second half of the $19^{\text {th }}$ century, following the expansion of exports (see Figure 4). However, this reached its peak at the beginning of the $20^{\text {th }}$ century. From then, until the Great Depression, we observe stagnation with a high level of volatility, just as for the export quantum. The impact of the Great Depression on imports quantum was profound, following the evolution of the export quantum and the collapse in export and import prices.

Figure 4 - Import quantum index, 1850-1938 (1913=100)

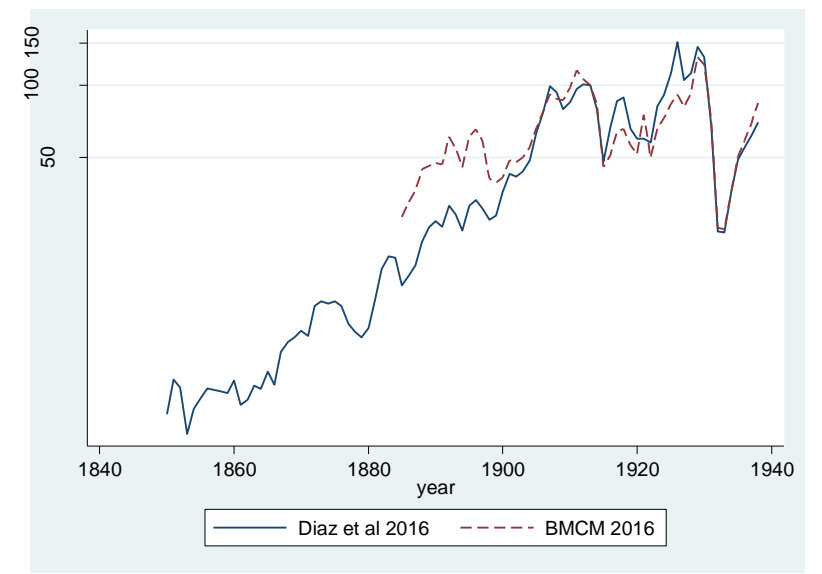

Source: Badia-Miró and Carreras-Marín (2016) and Díaz et al. (2016)

Discrepancies between both series are important before the $20^{\text {th }}$ century, due to differences observed in import prices. In Badia-Miró and Carreras-Marín (2016), the 
figures for the 1880s showed higher levels (in 1880, for example, their figures are nearly double those of Diaz et al. (2016)), which also implies a smaller growth rate in quantum during the nitrate expansion. Although the period covered by Díaz et al. (2016) is broader and provides a long run view of trade performance in Chile, the methodology proposed by Badia-Miró and Carreras-Marín (2016) seems to achieve more accuracy. For these reasons we consider both series in later sections of this paper.

\section{Chilean Trade: Composition, Origin and Destination}

The Chilean official reports of international trade were very detailed concerning the types of tradable goods. However, those reports did not provide a systematic and regular classification that made aggregation and standardisation into homogeneous categories easy, at least, not until the end of the 19th century (Cuevas, 1901). Díaz et al. (2016) made great efforts to compile and provide the shares of exports reclassified into big sectors: Agricultural, Mining, Manufactured and Others. These figures could then be transformed into current dollars, multiplying the shares by the total exports value. To build this series, they considered the following sources:

- 1844-1869: shares from Carmagnani (1971: Appendix 10).

- 1870-1930: shares from Kirsch (1977: pp. 161-62) and Butelmann et al. (1981: Table 8).

As can be observed in Figure 5, the main exports of Chile between 1844 and 1940 were mineral products, especially copper and nitrate. 
Figure 5 - Chilean exports composition, 1844-1940.

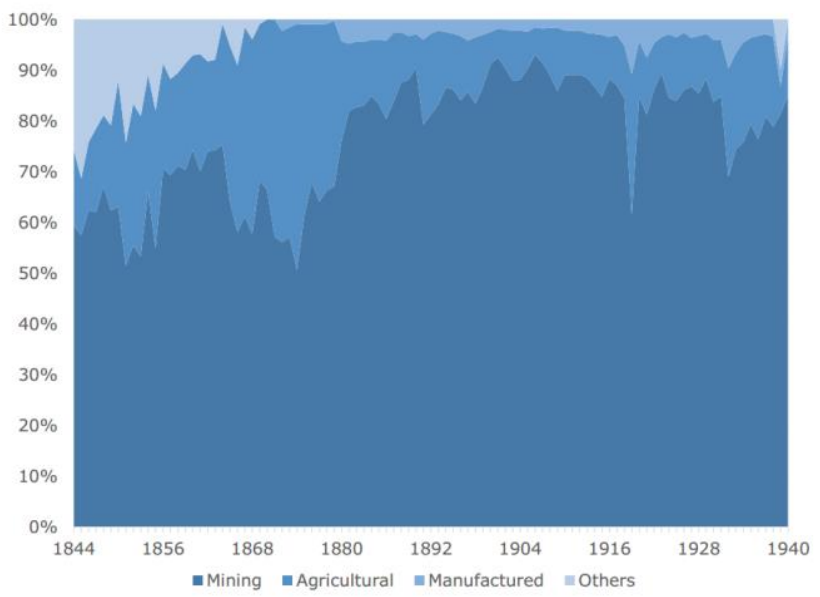

Source: Díaz et al (2016).

Regarding the main destinations for Chilean exports, the conventional picture of the British market as the main destination of Chilean exports during the 19th century, does not appear to be well founded. As Llona-Rodríguez (2012) has pointed out, between 1870 and 1903, the official reports registered the destination of exports in terms of the "destination of the vessel". This procedure does not take into account the problem of transhipment: ships going to London, for example, might have carried cargoes whose final destination was France, Germany or other Mediterranean ports. For the years 1902 and 1903, Estadística Comercial published both the destination of the vessel and final destination of the shipment. Starting in 1904, the destination of exports seems to be computed in terms of the final destination of the shipment. The share of exports to Britain is greatly reduced when using this second accounting method. From 1914 to 1921 and from 1929 to 1935, a large percentage of nitrate exports were a la orden, meaning without destination at the time of the shipment (Llona-Rodríguez, 2012: p. 8). Nevertheless, most of the authors who have worked on this topic assume the Chilean statistics to be reliable. 
According to Bulmer-Thomas (2003: Table 3.6), in 1913 the main destinations of Chilean exports were the United Kingdom (38.9\%), Germany (21.5\%), the United States $(21.3 \%)$ and France $(6.2 \%)$. Therefore, although it is plausible to suppose that Europe was the main market for Chilean products during the export-led growth model, the real size of the demand from each country is still open to debate.

As for imports, the Chilean official reports of international trade did not provide a systematic and regular classification that aggregated imports by standardised categories, until the end of the 19th century. To overcome this, Díaz et al. (2016) also compiled shares of imports by sector, classified as Agricultural, Mining, Manufactured and Others. As before, when these shares are multiplied by the total import values, we obtain the levels in current dollars. The sources are:

- 1844-1910: shares of Carmagnani (1971: Appendix 9).

- 1911-1966: shares of Díaz and Wagner (2004), based on official reports.

During the period 1844-1940, the main imports of Chile were manufactured goods and coal (Figure 6).

Figure 6 - Chilean imports composition, 1844-1940.

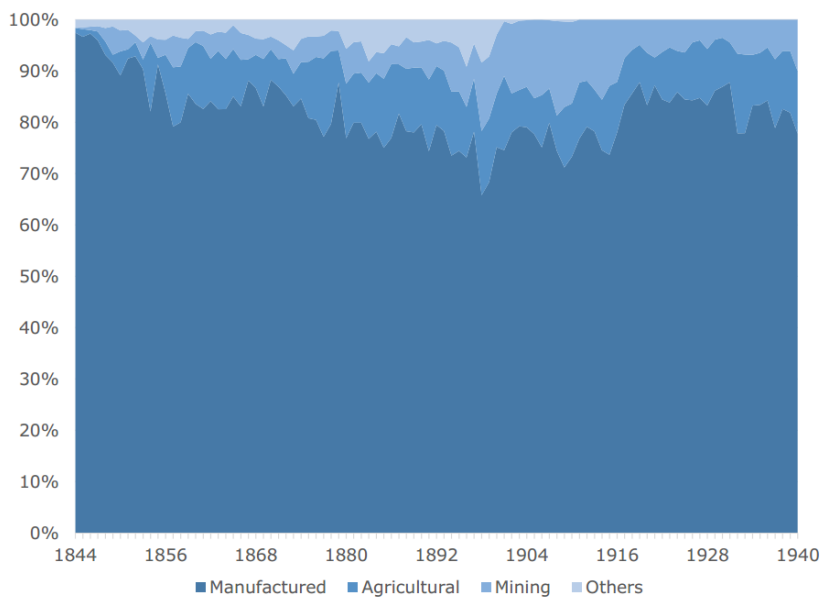


Source: Díaz et al. (2016).

Ducoing and Tafunell (2013) discuss the accuracy of the manufactured imports figures, checking the Chilean reports against official trade statistics from Germany, the United States and Great Britain. They conclude that, although problems in goods classification persist, both series show a similar trend. Nevertheless, it is not easy to identify the origin of Chilean imports. Between 1870 and 1903, the official source, Estadística Comercial, assigned imports to the country of the port of origin of the vessel, while from 1904, imports were allocated according to the country of origin of the goods (when it was known). In other cases, the former rule was applied (Llona-Rodriguez, 2012).

With the above-mentioned caveat in mind, Table 1 shows a reduction in the share of British imports and an increase in the prominence of Germany and the United States, as import suppliers to Chile, between 1880 and 1913.

Table 1 - Chilean imports by origin as percentage of total imports.

\begin{tabular}{|c|c|l|l|l|}
\hline & 1870 & 1885 & 1900 & 1913 \\
\hline England & 45,2 & 38,7 & 33,1 & 30,0 \\
\hline France & 21,5 & 16,2 & 7,2 & 5,5 \\
\hline Germany & 9,5 & 17,8 & 26,7 & 24,6 \\
\hline Peru & 5,2 & & & \\
\hline United States & 5,3 & 6,8 & 9,4 & 16,7 \\
\hline
\end{tabular}

Source: 1870-1900, Estadística Comercial, selected years; 1913, Bulmer-Thomas (2003: Table 3.7). 


\section{Accuracy of Figures on Chilean Bilateral Trade with its Main Partners}

Allen and Ely (1953) and Morgernstern (1963) criticised the use of foreign trade statistics sources, due to their low level of accuracy when comparing different sources recording the same flow (imports of country A from country B should be the same as the exports of country B to country A). The criticisms in these works were later qualified by Federico and Tena-Junguito (1991) and Tena-Junguito (1991), who claimed that foreign trade sources could be a useful tool for the study of economics history before WWII, if the shortcomings in geographical and sectorial assignment were considered. Other works have focused on the study of Latin American foreign trade statistics. Authors such as Carreras-Marín and Badia-Miró (2008) ${ }^{4}$, validate the use of this source and point out its superior quality owing to a better geographical assignment. Other authors have deeply analyzed and validated specific countries' statistics, such as Argentina (Carreras-Marín and Rayes, 2015; Tena-Junguito and Willebald, 2013), Uruguay (Bonino-Gayoso et al., 2015) and Brazil (Absell and Tena-Junguito, 2016). Morgernstern (1963) quantifies the level of accuracy of a country thus:

$$
I_{i j}=\frac{X_{i j}}{M_{j i}} \cdot 100
$$

where $\mathrm{I}_{\mathrm{ij}}$ is the Morgernstern index, $\mathrm{X}_{\mathrm{ij}}$ is the exports of country $i$ to country $j$ and $\mathrm{M}_{\mathrm{ji}}$ is the imports of country $j$ from country $i$. Discrepancies found between the industrialised countries were huge; most of the $25 \%$ was expected, due to differences between CIF or FOB valuations, and with unexpected signs. Later, Federico and Tena-Junguito (1991) consider geographical assignment problems and correct this index with a regional index which includes the sum of bilateral imports and exports of both sources. The results

\footnotetext{
${ }^{4}$ Carreras-Marín and Badia-Miró (2008) check the accuracy of Latin American sources in both magnitudes, volume and prices. In both cases (considering coal) confirm the geographical assignment problem.
} 
obtained by these authors, as we have said, substantially reduce the levels of inaccuracy. Their method is expressed thus:

$$
F T_{i j}=\frac{\sum X_{i j}}{\sum M_{j i}} \cdot 100
$$

where $\mathrm{FT}_{\mathrm{ij}}$ is the Federico and Tena index, $\mathrm{X}_{\mathrm{ij}}$ are the exports of country $i$ to country $j$ and $\mathrm{M}_{\mathrm{ji}}$ are the imports of country $j$ from country $i$. This equation could equally consider whole countries or regions.

If we compute the Morgernstern index for Chile and its main trade partners (namely the USA, the UK, Germany, Belgium, France, Argentina and Bolivia), we observe a clear pattern of accuracy, worsening around the end of the 1920s and 1930s, in most cases (see Figure 7). Exchange rate volatility associated with the Great Depression could explain most of the discrepancies. However, we observed better results when comparing trade with the USA, the UK, France and Argentina before WWI, during the nitrate expansion after the Pacific War. We could also include Germany in this group, except for the years around 1880 when discrepancies arise. The case of Belgium has to be considered separately because we observe huge discrepancies during most of the period. The reason behind that (and the lower level of trade reported by Belgium) could be related to a bad geographical assignment of the Belgium trade statistics for imports. 
Figure 7 - Morgernstern index for Chilean exports to their main trade partners, 1850-1938.

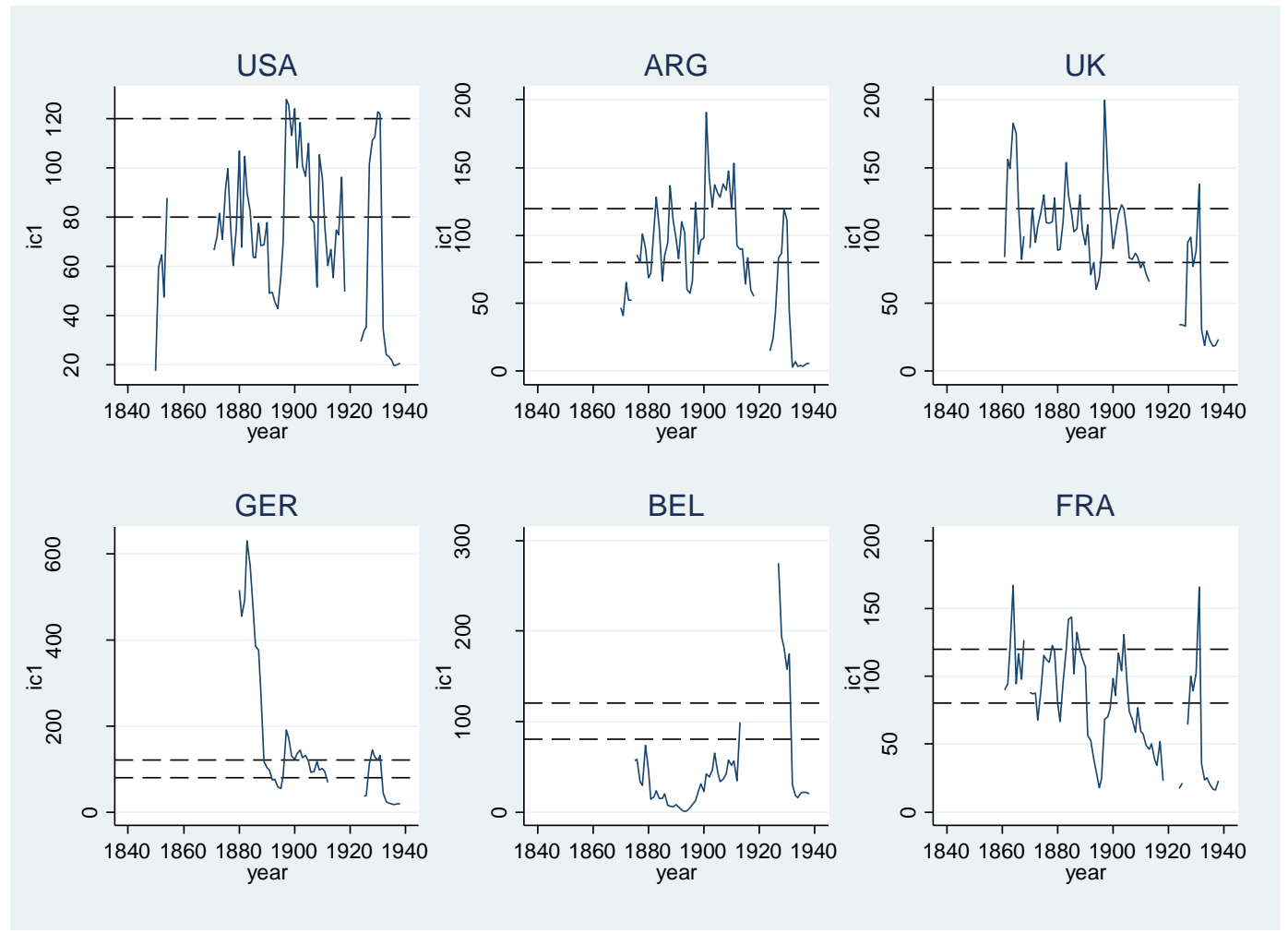

Source: Own elaboration based on sources described in the text. Lines indicate the upper and the lower band for $25 \%$ error around 100 which indicate that both sources show the same figures.

When considering Chilean imports and European exports, the accuracy worsened (Figure 8). Only trade with the UK and the USA seem to fit quite well. Germany and France joined Belgium in the group of countries with poor levels of accuracy. We can confirm that when we considered exports of these countries to the whole of South America, the huge discrepancies observed when considering bilateral trade, disappeared (so these were mainly due to bad geographical assignment, as Carreras-Marín and BadiaMiró (2008) pointed out). At the same time, these results confirm our hypothesis that the Chilean sources were good enough to be used. 
Figure 8 - Morgernstern index for Chilean imports to their main trade partners, 1850-1938.

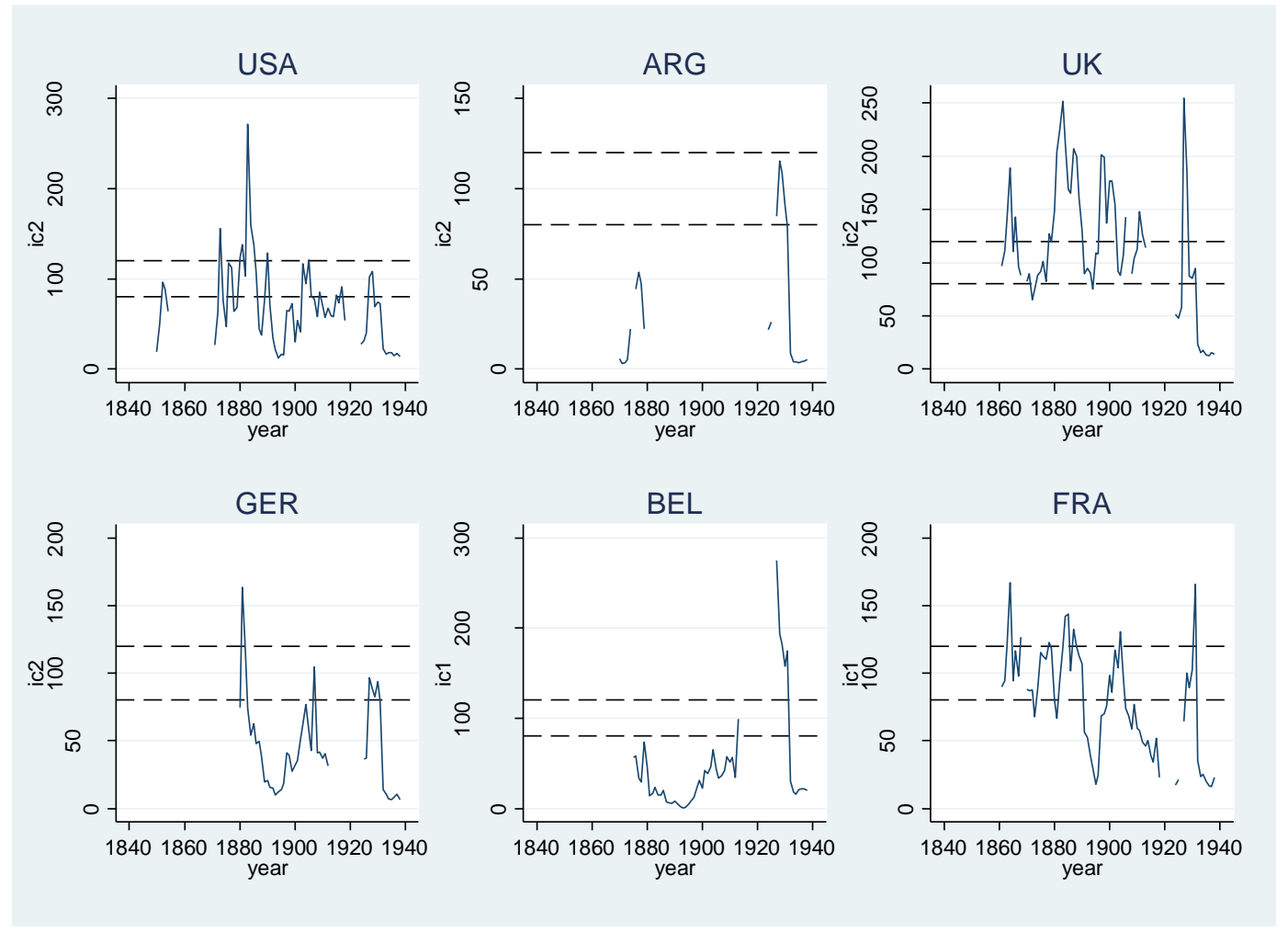

Source: Own elaboration based on sources described in the text. Lines indicate the upper and the lower band for $25 \%$ error around 100 which indicate that both sources show the same figures.

We also obtained the Federico and Tena index for the accuracy of Chilean exports to their main European partners (with and without the US). In this case, the results do not confirm the hypothesis that some of the discrepancies could be explained by bad geographical assignments. That is, Chilean trade statistics did not suffer from bad geographical assignment, while previous results would confirm that European trade statistics did suffer from this problem. Figure 9 shows that only a few years exhibited discrepancies lower than the $25 \%$ threshold assumed by the authors. Although we have not considered other European countries, such as Spain, Italy or the Netherlands, we could assume that the sample is representative of most European trade. Other possible 
explanations for these discrepancies could be related to differences between domestic and international prices or high trade costs that were not reported. When we repeat the exercise considering only the European sample or other South American countries, the results are similar and the conclusions are the same.

Figure 9 - Tena index for Chilean exports with their main trade partners, 1850-1938.

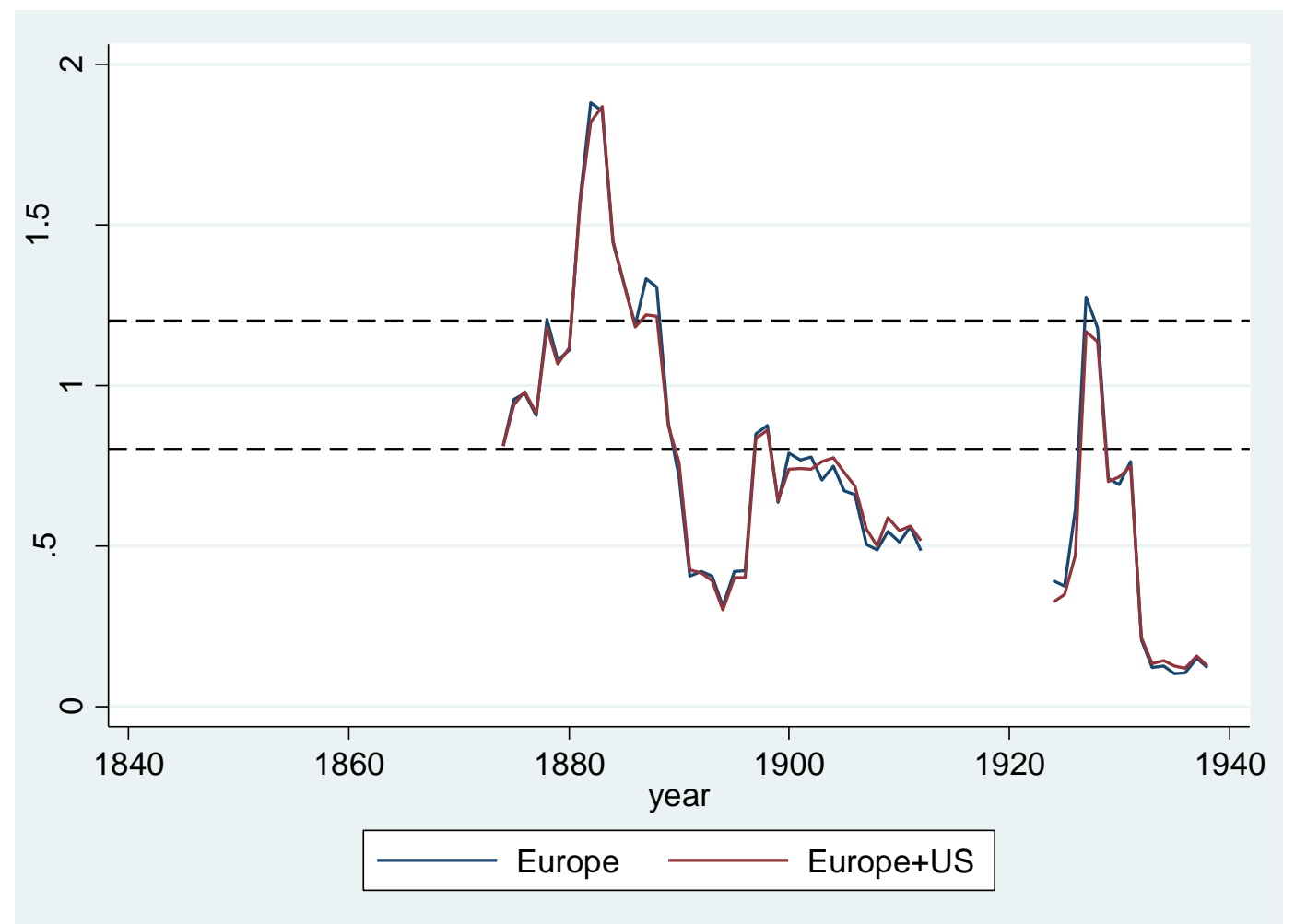

Source: Own elaboration based on sources described in the text.

By comparison, when we observe figure 10, we can confirm that Chilean imports and European exports were very similar, assuming the differential of $25 \%$, at least for the years before World War I. The Federico and Tena index performs better when we consider only Europe, at least, for the figures before the 1920s. This result confirms the explanation of bad geographical assignment in some European sources. Moreover, huge problems arose during the Great Depression, jointly with the lack of availability of data 
in Europe and the US during the wars. By contrast, Chilean trade statistics are available for the whole period.

Figure 10 - Tena index for Chilean imports with their main trade partners, 1850-1938.

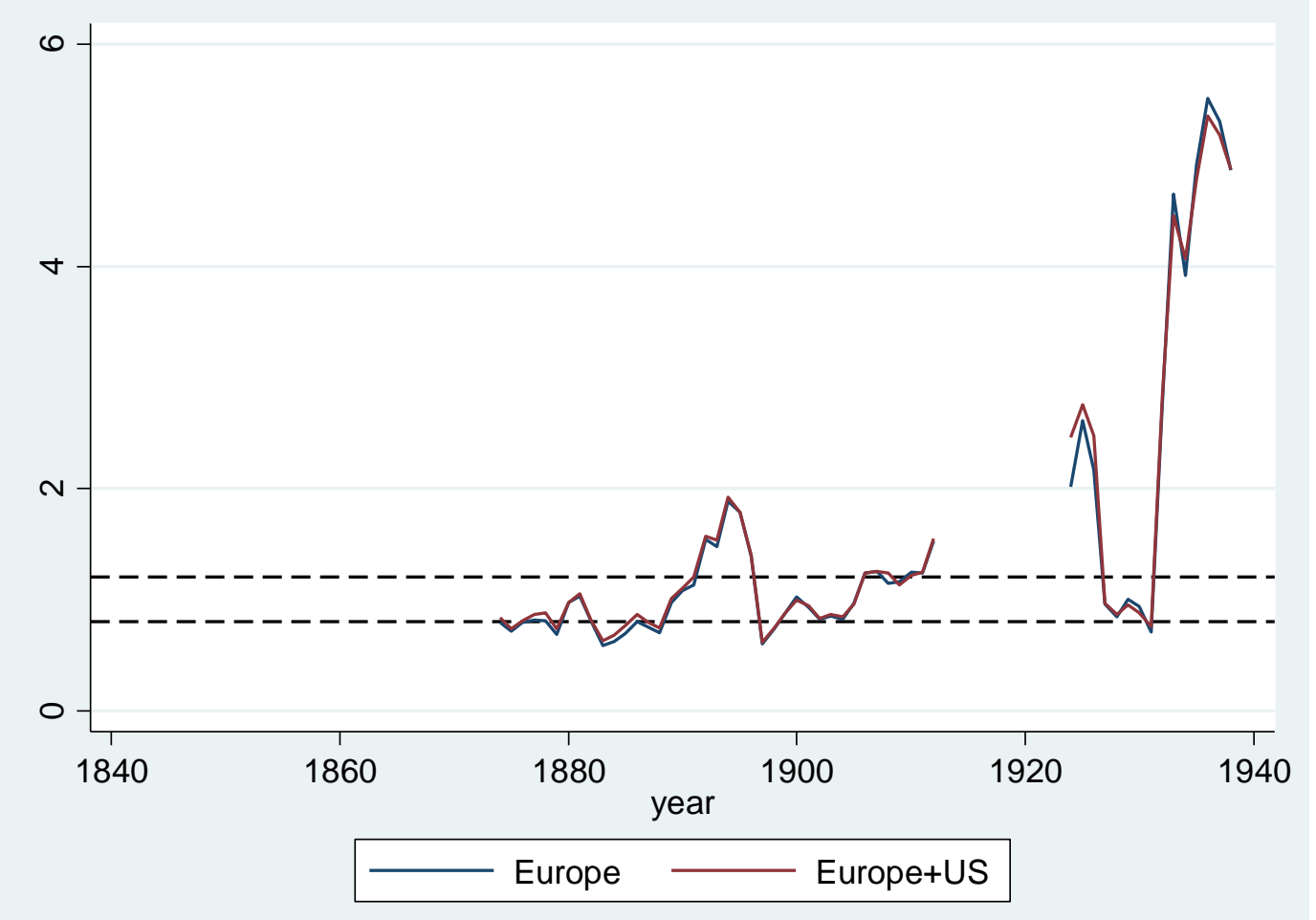

Source: Own elaboration based on sources described in the text.

To sum up, the accuracy in matching foreign trade statistics supports the view that the use of Chilean foreign trade statistics to analyse Chilean trade is acceptable. However, discrepancies are higher for imports than for exports, because problems related to geographical assignment are significant, specifically for European countries. Moreover, we observe important valuation problems during the 1920s, after WWI.

\section{Final Remarks}

Chilean foreign trade statistics are usually considered one of the most reliable sets of figures in Latin America. We discuss most of the existing total import and export 
figures used in works focused on Chile. In all cases, the original data come from the Chilean official source of foreign trade statistics and the existing discrepancies among them lie in the exchange rate used (local currency to \$US or to pounds sterling), or in the price index considered to convert current figures to constant figures. Accuracy tests partially confirm the reliability of bilateral data, especially when we assume the existence of some problems related to geographical assignments.

Above all, these figures confirm the high impact of exports on economic growth, especially during the nitrate era, due to the purchasing power of exporters alongside the expansion of aggregate exports, the downward trend in import prices (which is still being debated), and the high level of fiscal revenues.

By contrast, import price index series (and terms of trade) are still a subject of debate, and the existing figures show very different patterns, especially for import prices during the nitrate cycle. If we observe the main trends, there is a rebound in export prices, from the end of the $19^{\text {th }}$ century, associated to the saltpetre expansion. Import prices followed a downward trend, which started in the mid- $19^{\text {th }}$ century and lasted until World War I, after which prices became stagnant during the 1920s, until the arrival of the Great Depression.

\section{Bibliography}

ABSELL, C. D. and TENA-JUNGUITO, A. (2016). "Brazilian Export Growth and Divergence in the Tropics during the Nineteenth Century." Journal of Latin American Studies 48 (4), pp. 677-706.

ALLEN, R. G. D. and ELY, J. E. (1953). International Trade Statistics. New York, USA.: John Wiley \& Sons.

BADIA-MIRÓ, M. and CARRERAS-MARÍN, A. (2016). "Terms of Trade in Latin America (1900-1950): New Empirical Evidence for Chile, Brazil, Argentina and Peru." 
Paper presented in Sesión: Industrialización Antes de La ISI. Congreso Latinoamericano de Historia Económica V. Sao Paulo, Brasil.

BADIA-MIRÓ, M., CARRERAS-MARÍN, A. and MEISSNER, C. M. (2018). “Geography, Policy, or Productivity? Regional Trade in Five South American Countries, 1910-50.” Economic History Review 71 (1), pp. 236-266.

BADIA-MIRÓ, M. and DIAZ-BAHAMONDE, J. (2017). “The Impact of Nitrates on the Chilean Economy, 1880-1930" in KUNTZ, S. (ed). The First Export Era Revisited. Reassessing its Contribution to Latin American Economies. Palgrave Macmillan, Cham, Switzerland.

BANCO CENTRAL DE CHILE. (1962). Balanza de Pagos 1960. Santiago de Chile, Chile.: Departamento de Estadísticas, Banco Central de Chile. Talleres Gráficos "La Nación”.

BARBIERI, K. and KESHK, O. (2012). "Correlates of War Project Trade Data Set Codebook, Version 3.0.” http://correlatesofwar.org. (accessed 2017-03-17).

BARBIERI, K., KESHK, O. and POLLINS, B. (2009). “TRADING DATA: Evaluating Our Assumptions and Coding Rules." Conflict Management and Peace Science 26 (5), pp. 471-95.

BONINO-GAYOSO, N., TENA-JUNGUITO, A. and WILLEBALD, H. (2015). “Uruguay and First Globalization: On the Accuracy of Export Performance, 1870-1913." Revista de Historia Económica. 33 (2), pp. 287-320.

BRAUN, J., BRAUN, M., BRIONES, I., DÍAZ, J., LÜDERS, R. F., and WAGNER, G. (2000). "Economía Chilena 1810 - 1995: Estadisticas Históricas." Documentos de Trabajo - PUC, no. 187.

BROWN, J. R. (1963). "Nitrate Crises, Combinations, and the Chilean Government in the Nitrate Age." The Hispanic American Historical Review 43 (2), pp. 230-46. 
BULMER-THOMAS, V. (2003). The Economic History of Latin America since Independence. Cambrige, UK: Cambrige University Press.

BUTELMANN, A., CORTES-DOUGLAS, H., and VIDELA, P. (1981). “Proteccionismo En Chile: Una Visión Retrospectiva.” Cuadernos de Economía 18 (54), pp. 141-94.

CARMAGNANI, M. (1971). Sviluppo Industriale E Sottosviluppo Economico. Il Caso Cileno (1860-1920). Torino: Fondazione Luigi Einaudi.

CARRERAS-MARÍN, A. and BADIA-MIRÓ, M. (2008). "La Fiabilidad de La Asignación Geográfica En Las Estadísticas de Comercio Exterior: América Latina Y El Caribe (1908-1930).” Revista de Historia Económica, 26 (3), pp. 355-73.

CARRERAS-MARÍN, A. and RAYES, A. (2015). “La Fiabilidad En La Distribución Geográfica de Las Exportaciones Argentinas, 1875-1913." America Latina En La Historia Económica 22 (3), pp. 177-212.

CARRERAS-MARÍN, A., BADIA-MIRÓ, M. and PERES CAJÍAS, J. (2013). "Intraregional Trade in South America, 1912-1950: The Cases of Argentina, Bolivia, Brazil, Chile and Peru.” Economic History of Developing Regions, 28 (2), pp.1-26.

CLAVEL, C. (1990). “Los Términos de Intercambio En El Largo Plazo, 1860-1900.” In Encuentro Anual de Economistas de Chile. Chile.

COLLIER, S. and SATER, W. F. (2004). A History of Chile, 1808 - 2002. Cambridge University Press.

CUEVAS, J. (1901). Resumen de La Hacienda Pública de Chile Desde La Independencia Hasta 1900. Santiago de Chile, Chile.: Dirección Jeneral de Contabilidad. DÍAZ, J., ROLF. L. and WAGNER, G. (2016). Chile, 1810-2010. La República En Cifras. Historical Statistics. Santiago de Chile, Chile.: Ediciones Universidad Católica de Chile. 
DÍAZ, J. and WAGNER, G. (2004). "Política Comercial: Instrumentos Y Antecedentes. Chile En Los Siglos XIX Y XX.” PUC Economics Institute Working Paper 223. Santiago de Chile, Chile.

DUCOING, C. and TAFUNELL, X. (2013). "Formación bruta de capital en bienes de equipo en Chile, 1856-1930. Fuentes nacionales y extranjeras." América Latina en la historia económica 20 (1), pp. 5-34.

ECLAC. (1951). Economic Survey of Latin America, 1949. Santiago de Chile, Chile.: United Nations. Department of Economic Affairs. Secretariat of the Economic Comission for Latin America.

(1976). “America Latina: Relación de Precios de Intercambio.” Cuadernos Estadísticos de La CEPAL 1 (4).

FEDERICO, G. and TENA-JUNGUITO, A. (1991). "On the Accuracy of Foreign Trade Statistics (1909-1935): Morgenstern Revisited." Explorations in Economic History 28 (3), pp. 259-73.

(2016). "World Trade, 1800-1938: A New Data-Set." EHES WORKING PAPERS IN ECONOMIC HISTORY. no. 93.

FEINSTEIN, C. H. (1972). National Income, Expenditure and Output of the United Kingdom, 1855-1965. Cambridge, MA, MA: Cambridge University Press.

GOOTENBERG, P. E. (1989). "Niveles de Precios En Lima Del Siglo Diecinueve: Algunos Datos E Interpretaciones.” Revista de Economía 12 (24), pp. 137-205.

HOFMAN, A. (2000). The Economic Development of Latin America in the Twentieth Century. Economic Reforms Series. Vol. 54. Economic Reform Series. Cheltenham: Elgar. 
IBÁÑEZ, G. (1912). Recopilación de Las Disposiciones Vigentes Relativas a La Conversión Y Emisión de Billetes, a La Acuñación de Monedas Y a Los Bancos. Santiago de Chile, Chile.: Imprenta Universitaria.

KIRSCH, H. W. (1977). Industrial Development in a Traditional Society. The Conflict of Entrepreneurship and Modernization in Chile. Gainesville: The University press of Florida.

LLONA RODRÍGUEZ, A. (2012). "On the Accuracy of Chilean Foreign Trade Statistics during the Nitrate Boom: 1870-1935." Mimeo.

MAMALAKIS, M. J. (1978). "Historical Statistics of Chile: An Introduction.” Latin American Research Review 13 (2), pp. 127-37.

MELLER, P. (1998). Un Siglo de Economía Política Chilena (1890-1990). Santiago de Chile, Chile.: Andrés Bello.

MITCHELL, B. R. and DEANE, P. (1962). Abstract of British Historical Statistics. Cambridge, MA.: Cambridge University Press.

MORGERNSTERN, O. (1963). On the Accuracy of Economic Observations. New Jersey, USA: Princeton University Press.

MOXLAD. 2011. "Montevideo - Oxford Latin American Economic History Database (MOxLAD).” http://moxlad.fcs.edu.uy/.

OCE. (1925). Anuario Estadístico de La República de Chile 1925. Santiago, Chile.: Oficina Central de Estadística, Sociedad Imprenta y Litografía Universo.

PALMA, J. G. (1979). “Growth and Structure of Chilean Manufacturing Industry from 1830 to $1935 . "$ PhD. Thesis. University of Oxford.

RECTOR, J. (1985). “El Impacto Económico de La Independencia En América Latina: El Caso de Chile.” Historia, 20, pp. 295-318. 
RICardo. (2016). “The RICardo Project. Trade between Nations from C. 1800 to 1938." Database. http://ricardo.medialab.sciences-po.fr/\#/.

SNECCh. (1930). Estadística Chilena, Sinopsis 1930. Santiago de Chile, Chile.: Servicio Nacional de Estadísticas y Censos de Chile.

SOCIETE DES NATIONS. (1928). Memorandum Sur Le Commerce International et Sur Les Balances de Paiements, 1912-1926. Geneve, Switzerland.: Publications de la Societe des Nations.

TENA-JUNGUITO, A. (1991). “Las Estadísticas Históricas Del Comercio Internacional (1890-1960): Fiabilidad y Comparabilidad." Servicio de Estudios. Estudios de Historia Económica. Banco de España. Universidad de Alcalà de Henares.

TENA-JUNGUITO, A. and WILLEBALD, H. (2013). "On the Accuracy of Export Growth in Argentina, 1870-1913." Economic History of Developing Regions 28 (1), pp. $28-68$. 